\title{
EDITORIAL
}

\section{En tiempos de COVID}

\author{
Giubi Bobeda, Jorge ${ }^{1}$
}

${ }^{1}$ Universidad Nacional de Asunción, Facultad de Ciencias Médicas, Hospital de Clínicas. San Lorenzo, Paraguay.

El Hospital de Clínicas iniciaba sus tareas asistenciales en el mes de julio del año 1894, cumpliendo así en este año, 126 años de vida institucional en plena pandemia SARS COV $2(1,2)$. Desde sus inicios el Hospital se constituyó en un referente del sistema de salud del Paraguay, brindando atención sin distinción, a todos los habitantes de nuestro país, y sobre todo a los más vulnerables, muchos de ellos llegando a nuestras urgencias sólo con lo que portaban y con la esperanza de recuperar su salud. A través de los años situaciones difíciles han golpeado a nuestro Hospital, Pandemia en 1918, conflicto bélico en 1932, persecuciones ideológicas y políticas, sin embargo, esto nunca afecto el desempeño y la asistencia brindada a la ciudadanía haciendo notar así las características que nos destacan, la solidaridad y empatía de los profesionales que llevan adelante este glorioso Hospital.

Hoy ante este nuevo embate, una patología viral iniciada al otro lado del mundo, que en sólo 3 meses hizo su aparición en el Paraguay, el COVID 19, nos obligó a replantear todo el sistema asistencial, actualizar nuestros protocolos, y sobre todo la gran responsabilidad de brindar al funcionario las herramientas necesarias para dar asistencia en forma segura $(3,4)$.

Al inicio pasamos una etapa muy difícil que se caracterizó por el pánico generalizado, que con capacitación y el acompañamiento de valiosos profesionales que llevaron adelante todo un proceso de reconversión, pudo transformar en respeto y prudencia la actitud del personal ante este novel virus.

Los recursos humanos asignados a la atención directa, en áreas de contingencia, demostró su capacidad y valor al estar al frente de esta dura batalla que se iniciaba, sin muchos recursos y, con poca ayuda del gobierno estamos día a día luchando para sostener las actividades hospitalarias, brindar la mayor seguridad a nuestros funcionarios $y$, así asegurar la continuidad de los servicios.

Existe un factor importante que debemos tener en cuenta, la salud mental, que está siendo afectada seriamente y muchas veces es imperceptible, en donde el entorno laboral juega un papel importante, debiendo nosotros transformarlo en armónico y agradable en base al apoyo, solidaridad y respeto para con nuestros compañeros de trabajo.

Como una colega en una reunión del Comité de Contingencia remarco "Este virus vino a auditar nuestro Hospital", dejando en claro que deberíamos de rever y corregir absolutamente todas nuestras conductas, lo que necesariamente va a cambiar para siempre el modo en que nos manejamos. La vuelta a la normalidad tal como la vivíamos antes ya no será posible, el concepto de "NUEVA NORMALIDAD" debe instalarse como conducta, en donde las medidas de higiene y distanciamiento estén siempre presentes en nuestras labores diarias $(5,6)$.

Solo la solidaridad entre todos los que vivimos el día a día en el Hospital nos podrá

Autor correspondiente: Prof. Dr. Jorge Giubi Bobeda. Universidad Nacional de Asunción, Facultad de Ciencias Médicas, Hospital de Clínicas, Director General Asistencial. San Lorenzo, Paraguay. E-mail: jorgegiubi@gmail.com

Fecha de recepción el 1 de Agosto del 2020; aceptado el 4 de Agosto del 2020. 
sacar adelante, dejando de lado los intereses personales y priorizar los generales, debemos revivir los valores que siempre caracterizaron a nuestro querido Hospital de Clínicas y convertirlos en nuestra mayor fortaleza, así unidos y en trabajo mancomunado podremos superar no sólo está, sino cualquier situación adversa que se nos pueda presentar.

Está en nosotros que futuras generaciones sigan manteniendo el espíritu de lucha que es el sello distintivo de nuestra Institución, y esto no lo lograremos con discursos vacíos, sino con el ejemplo, cumpliendo nuestras labores con responsabilidad y excelencia.

Al Hospital de Clínicas lo hacen todos los que día a día dejan sus hogares y sus familias para servir a otros, con respeto, cariño y profesionalismo, es justo rendir un homenaje a todos ellos que en silencio cumplen su labor por la salud del pueblo paraguayo.

\author{
Prof. Dr. Jorge Giubi Bobeda \\ Director General Asistencial \\ Hospital de Clínicas \\ F.C.M.-U.N.A.
}

\section{REFERENCIAS BIBLIOGRAFICAS}

1. Tang D, Comish P, Kang R. The hallmarks of COVID-19 disease. PLoS Pathog. 2020;16(5):e1008536. Published 2020 May 22. doi:10.1371/journal. ppat.1008536.

2. 2.Tu H, Tu S, Gao S, Shao A, Sheng J. Current epidemiological and clinical features of COVID-19; a global perspective from China. J Infect. 2020;81(1):19. doi:10.1016/j.jinf.2020.04.011

3. $\mathrm{Hu} \mathrm{D}, \mathrm{Lou} X, \mathrm{Xu} Z$ Z, et al. More effective strategies are required to strengthen public awareness of COVID-19: Evidence from Google Trends. J Glob Health. 2020;10(1):011003. doi:10.7189/jogh.10.011003

4. Ortiz-Prado E, Simbaña-Rivera K, Gómez-Barreno $L$, et al. Clinical, molecular, and epidemiological characterization of the SARS-CoV-2 virus and the Coronavirus Disease 2019 (COVID-19), a comprehensive literature review;. Diagn Microbiol Infect Dis. 2020;98(1):115094. doi:10.1016/j. diagmicrobio.2020.115094.

5. Allam M, Cai S, Ganesh S, et al. COVID-19 Diagnostics, Tools, and Prevention. Diagnostics (Basel). 2020;10(6):409. Published 2020 Jun 16. doi:10.3390/diagnostics10060409.

6. Chu DK, Akl EA, Duda S, et al. Physical distancing, face masks, and eye protection to prevent person-toperson transmission of SARS-CoV-2 and COVID-19: a systematic review and meta-analysis. Lancet. 2020;395(10242):1973-1987. doi:10.1016/S01406736(20)31142-9. 


\title{
EDITORIAL
}

\section{In COVID times}

\author{
Giubi Bobeda, Jorge ${ }^{1}$ \\ ${ }^{1}$ Universidad Nacional de Asunción, Facultad de Ciencias Médicas, Hospital de Clínicas. San Lorenzo, Paraguay.
}

The Hospital de Clínicas began its care tasks in the month of July 1894, thus it reaches the age of 126 years of institutional life in the middle of the SARS COV 2 pandemic $(1,2)$. Since its establishment, the Hospital has become a point of reference in the health system of Paraguay, providing care assistance without discrimination, specially to the most vulnerable people, many of them arriving at our emergency rooms only with what they were carrying and hoping to recover their health. Over the years difficult situations have hit our Hospital, for example a pandemic in 1918, a war in 1932, and also ideological and political persecutions. However, this never affected our performance as well as our care assistance program, emphasizing thus the characteristics that stand out to us: solidarity and empathy of the professionals who take forward this glorious Hospital.

Nowadays, a viral pathology started on the other side of the world, which in just three months made its appearance in Paraguay- the Coronavirus (COVID 19), forced us to rethink our entire healthcare system, update our medical protocols, and specially to provide to health officials with the necessary tools for a safe assistance $(3,4)$.

At the beginning of the pandemic, we had a very difficult stage because of a widespread panic. This critical time, however, was undone with training and support of valuable professionals who carried out a whole process of reconversion, in which it was possible to transform the attitude of the staff towards this novel virus into respect and prudence.
The human resources assigned to direct care on contingency areas demonstrated their capacity and courage by being at the forefront of this tough fight that was beginning with scarcity of resources and little governmental support. But today we are day by day struggling to sustain hospital activities and to provide the greatest security to our health officials and thus to ensure the continuity of services.

There is a relevant element that we must take into account: the mental health, which is being seriously affected, often imperceptibly. In this context, the work environment plays an important role and we must transform it into a harmonious and pleasant placed with support, solidarity, and respect for all co-workers.

As a colleague at a meeting of the Contingency Committee remarked, "This virus came to audit our hospital", making it clear that we should absolutely review and amend our conducts. This will necessarily change the way we handle ourselves forever. The return to normality as we lived it before will no longer be possible. The notion of "THE NEW NORMAL" must be installed as a pattern of conduct, in which hygiene and social distancing are always present in our daily tasks $(5,6)$.

Only solidarity between all of us who live day to day in the hospital will move us forward, leaving personal interests aside and prioritizing the common good. We must restore the values that have always characterized our beloved Hospital de Clínicas and make them our greatest strength. Only standing together, we will be able

Autor correspondiente: Prof. Dr. Jorge Giubi Bobeda. Universidad Nacional de Asunción, Facultad de Ciencias Médicas, Hospital de Clínicas, Director General Asistencial. San Lorenzo, Paraguay. E-mail: jorgegiubi@gmail.com

Fecha de recepción el 1 de Agosto del 2020; aceptado el 4 de Agosto del 2020. 
to overcome not only this situation but also any adverse situation that may arise in the future.

It is up to us that future generations continue to maintain the spirit of struggle, which is a feature of our institution. And this goal we will not achieve with empty speeches, but with example, carrying out our tasks with responsibility and excellence.

The Hospital de Clínicas is established by all those who day after day leave their homes and families to serve others with respect, affection, and professionalism. Therefore, it is fair to pay tribute to all of them who silently fulfill their tasks for the health of the Paraguayan people.

\author{
Prof. Dr. Jorge Giubi Bobeda \\ Director General Asistencial \\ Hospital de Clínicas \\ F.C.M.-U.N.A.
}

person transmission of SARS-CoV-2 and COVID-19: a systematic review and meta-analysis. Lancet. 2020;395(10242):1973-1987. doi:10.1016/S01406736(20)31142-9.

\section{REFERENCIAS BIBLIOGRAFICAS}

1. Tang D, Comish P, Kang R. The hallmarks of COVID-19 disease. PLoS Pathog. 2020;16(5):e1008536. Published 2020 May 22. doi:10.1371/journal. ppat.1008536.

2. 2.Tu H, Tu S, Gao S, Shao A, Sheng J. Current epidemiological and clinical features of COVID-19; a global perspective from China. J Infect. 2020;81(1):19. doi:10.1016/j.jinf.2020.04.011

3. Hu D, Lou X, Xu Z, et al. More effective strategies are required to strengthen public awareness of COVID-19: Evidence from Google Trends. J Glob Health. 2020;10(1):011003. doi:10.7189/jogh.10.011003

4. Ortiz-Prado E, Simbaña-Rivera K, Gómez-Barreno $L$, et al. Clinical, molecular, and epidemiological characterization of the SARS-CoV-2 virus and the Coronavirus Disease 2019 (COVID-19), a comprehensive literature review;. Diagn Microbiol Infect Dis. 2020;98(1):115094. doi:10.1016/j. diagmicrobio.2020.115094.

5. Allam M, Cai S, Ganesh S, et al. COVID-19 Diagnostics, Tools, and Prevention. Diagnostics (Basel). 2020;10(6):409. Published 2020 Jun 16. doi:10.3390/diagnostics10060409.

6. Chu DK, Akl EA, Duda S, et al. Physical distancing, face masks, and eye protection to prevent person-to- 